\title{
Az első tapasztalatok a palliatív onkoteamrendszer müködésével kapcsolatban a Pécsi Tudományegyetemen
}

\author{
Mangel László dr. ${ }^{1}$ - Lukács Miklós ${ }^{2}$ - Hajnal András dr. ${ }^{3}$ \\ Sárkány Henrik ${ }^{1}$ - Forgács-Menyhért Mónika ${ }^{1,2}$ - Varga Zsuzsanna dr. ${ }^{1}$ \\ Herendi Eszter dr. ${ }^{1}$ - Papp Emőke dr. ${ }^{1}$ - Jéglné Illés Zsuzsanna ${ }^{1}$ \\ Szigeti Nóra dr. ${ }^{4}$ - Almási Róbert $\mathrm{dr} .{ }^{5}$ - Ferencz Sándor dr. ${ }^{6}$ \\ Kanizsai Péter dr. ${ }^{7}$ - Sebestyén Andor dr. ${ }^{8}$. Csikós Ágnes dr. ${ }^{2}$
}

\footnotetext{
${ }^{1}$ Pécsi Tudományegyetem, Általános Orvostudományi Kar, Klinikai Központ, Onkoterápiás Intézet, Pécs

${ }^{2}$ Pécsi Tudományegyetem, Általános Orvostudományi Kar,

Alapellátási Intézet és Palliatív Medicina Tanszék, Pécs

${ }^{3}$ Pécsi Tudományegyetem, Általános Orvostudományi Kar, Klinikai Központ, Pszichiátriai és Pszichoterápiás Klinika, Pécs

${ }^{4}$ Pécsi Tudományegyetem, Általános Orvostudományi Kar, Klinikai Központ, II. Belgyógyászati Klinika, Pécs ${ }^{5}$ Pécsi Tudományegyetem, Általános Orvostudományi Kar, Klinikai Központ,

Aneszteziológiai és Intenzív Terápiás Intézet, Pécs

${ }^{6}$ Pécsi Tudományegyetem, Általános Orvostudományi Kar, Klinikai Központ, Sebészeti Klinika, Pécs ${ }^{7}$ Pécsi Tudományegyetem, Általános Orvostudományi Kar, Klinikai Központ, Sürgősségi Orvostani Tanszék, Pécs ${ }^{8}$ Pécsi Tudományegyetem, Általános Orvostudományi Kar, Klinikai Központ, Elnöki Hivatal, Pécs
}

Bevezetés és célkitüzés: Az előrehaladott, áttétes daganatos betegek megfelelő tüneti és életvégi ellátása, illetve ennek elérése komoly kihívás minden egészségügyi ellátó számára. A palliatív onkoteamrendszer kialakításával célunk a betegek időbeni palliatív ellátásba vonása és a konzekvencia nélküli sürgősségi kivizsgálások és ellátások számának lehetőség szerinti csökkentése volt.

Módszer és eredmények: A palliatív onkoteam megbeszéléseit kéthetente tartottuk meg; a team állandó tagjai palliatív szakorvos, onkológus, belgyógyász, pszichiáter, szakápoló, pszichológus voltak, de időszakosan más szakemberek is csatlakoztak. 2019 májusa és 2020 januárja között 93, előrehaladott stádiumú daganatos betegnél 97 eseti megbeszélést tartottunk, egy-egy ülésen 6-10 beteg esetét tárgyaltuk végig. Minden esetben meghatároztuk a beteg további palliatív ellátásának formáját (szakrendelésen jelentkezés, otthoni szakellátás, intézeti elhelyezés) és azt, hogy adott esetben még szóba jön-e további aktív onkológiai ellátás. A megbeszélésre került betegek esetében pár hónap eltelte után a felesleges sürgősségi megjelenések számában egyértelmú csökkenés mutatkozott.

Következtetés: A kezdeti, sokszor heves érzelmekkel is kísért megbeszélések rövid időn belül komoly operatív szakmai fórummá váltak. Úgy gondoljuk, hogy ez a rendszer is komolyan hozzájárulhat ahhoz, hogy az előrehaladott daganatos betegek időben palliatív szakellátáshoz jussanak, és ahhoz is, hogy a gyógyító onkológiai attitúd fokozatosan segítő orvosi hozzáállássá tudjon válni.

Orv Hetil. 2020; 161(34): 1423-1430.

Kulcsszavak: onkológia, palliatív medicina, onkoteam, sürgősségi ellátás

\section{The first experiences with the palliative tumor board discussions in the University of Pécs}

Introduction: Palliative, symptomatic and end-of-life care of advanced and metastatic cancer patients is a great challenge for every health care system. With the initiation and establishment of the multidisciplinary palliative tumor board (MPTB), our aims were the timely referral of patients to palliative care, and the avoidance of multiple unnecessary emergency visits and over-diagnostics without further treatment consequences. 
Method and results: The MPTB meetings were held biweekly. The core members of the team were: palliative care consultant, medical oncologist, internal medicine physician, psychologist, psychiatrist, and oncology and palliative medicine nurses. From May 2019 till January 2020, we discussed the medical history of 97 cases of 93 cancer patients with advanced disease states; in one meeting the team usually discussed over 6-10 complex patient histories. In every case we determined the actual form of the necessary palliative care, e.g., outpatient clinic, home care, or institutional referral, and we decided on further possible and realistic oncology treatment regimes. A few months after the introduction of the new MPTB, we detected a decrease of the unnecessary emergency unit referrals considering the patients whose histories were discussed.

Conclusions: Although the initial MPTB discussions had an intense emotional tone, they shortly became thoughtful and operational expert meetings. We believe that the MPTB system fully promotes the early and timely access of advanced cancer patients to appropriate palliative care and facilitates gradual changes in the medical oncologists' approach from the absolute curative determination to a supportive medical attitude.

Keywords: medical oncology, palliative care, tumor board, emergency unit

Mangel L, Lukács M, Hajnal A, Sárkány H, Forgács-Menyhért M, Varga Zs, Herendi E, Papp E, Jéglné Illés Zs, Szigeti N, Almási R, Ferencz S, Kanizsai P, Sebestyén A, Csikós Á. [The first experiences with the palliative tumor board discussions in the University of Pécs]. Orv Hetil. 2020; 161(34): 1423-1430.

(Beérkezett: 2020. március 25.; elfogadva: 2020. május 3.)

\section{Rövidítések}

BSC $=$ (best supportive care) legjobb támogató kezelés; ECOG = Eastern Cooperative Oncology Group; KPS = (Karnofsky Performance Scale) Karnofsky-teljesítményskála; POT = palliatív onkoteam; $\mathrm{WHO}=$ World Health Organization

Az onkológiai diagnosztika és terápia elmúlt 2-3 évtizedbeli látványos fejlődését manapság már senki sem kérdőjelezi meg. A pontosabb diagnosztika, az egyre hatékonyabb kezelések és már az áttétes betegségek kapcsán is elérhető többéves túlélési eredmények mellett ebben a fejlődési folyamatban fokozatosan egyre fontosabbá vált az életminőség szerepe, és az onkológiai rehabilitáció, illetve a megfelelő tüneti, palliatív terápia is szerves részévé vált a teljes körü onkológiai ellátásnak. Ezen folyamatnak betudhatóan a palliatív medicina, mint önálló orvosi tudományág, a daganatos betegek magas száma, aránya miatt joggal lett egyúttal onkológiai szubdiszciplína is. Természetesen a palliatív medicina onkológiai szerepéról és jelentőségéről számtalan nemzetközi és hazai szakirodalmi hivatkozás, ajánlás lelhető fel [1-7].

A palliatív orvoslás története a múlt század közepére és elsősorban az angolszász országokra vezethető vissza. A kezdeti időszakot leginkább Cicely Saunders és Elisabeth Kübler-Ross munkássága fémjelzi. A palliatív medicina az elmúlt 30-40 évben teljesen elfogadott önálló orvosi szakterületté és a rákbetegellátás integráns részévé vált, múködését pedig számtalan, mára már jól definiált irányelv szabályozza [1-5]. Magyarországon a palliatív orvoslás kezdete az 1980-90-es évekre datálható, hazánkban talán elsősorban Polcz Alaine, Muszbek Katalin és Hegedűs Katalin munkásságát kell kiemelni [8]. Azóta az ország számos részén alakultak palliatív-hospice intézmények, és bár számtalan nehézség mellett, de az utóbbi években kialakulni látszik a gyermekonkológiát is magában foglaló palliatív ellátási struktúra kiváló képzési fórumokkal, illetve önálló oktatással és szervezetekkel [614]. Ebben a folyamatban az elmúlt évek során a Pécsi Tudományegyetem egyfajta iránymutató szerepet játszott önálló tanszéki munkacsoporttal, palliatív mobil team és integrált ellátórendszer kialakításával [6-7].

Visszatérve az onkológiai gyógymódok fejlődésére: a terápiás lehetőségek tárházának kiszélesedése és az akár tucatnyi vonalbeli kezelési opció sokszor azt a képzetet erôsíti, hogy a daganatos kórképek már tényleg krónikus betegségeknek tekinthetők, és szinte minden betegnél léteznek újabb és újabb hatékony gyógymódok. A mai világban valahol ezt a terápiás optimizmust várja el a külvilág, a média, a hozzátartozó és többnyire a beteg is. Ezért is nehéz az onkológus kezelőorvos számára, hogy kellő időben a palliatív szakember segítségét kérje, hiszen ez szinte minden résztvevő számára a gyógyulásról való lemondást jelenti. Pedig az előrehaladott, áttétes betegek esetében a korai (vagy legalább kellő időben történő) palliatív ellátásba vonás nemcsak az életminőség teljesen érthető és egyértelmű javulásával jár, hanem több tanulmány szerint ezzel élettartam-növekedés is elérhető, nem beszélve arról a tényről, hogy így csökkenhet a felesleges sürgősségi ellátások száma és az egészségügyi költségek mértéke, valamint a hozzátartozókra háruló - akár emocionális - teher is [15-17]. Így a legtöbb nemzetközi és hazai ajánlás is a korai palliatív ellátásba vonást javasolja az előrehaladott, áttétes daganatos betegeknél [1-6, 18-25].

Összességében azonban egy egyelőre nehezen kezelhető kérdésről beszélünk, a mindennapokban szinte folyamatosan ütközik egyfajta szakmai kihívás és az előrehaladott daganatos betegek testi-lelki jólétének elérésével kapcsolatos jogos igény. Persze a különböző közös 
képzések, a palliatív szakemberek onkoteammegbeszéléseken való részvétele és a jól múködő konzultációs rendszerek rengeteget segíthetnek eme dilemmák feloldásában. Mégis szükségszerünek látszik a folyamat optimálissá tétele szempontjából újabb esetmegbeszélési fórumok és minőségbiztosítási lépések keresése, éppen a betegjóllét optimális elérése és az egészségügyi kapacitások felesleges terhelésének elkerülése céljából. Azt is említettük, hogy Pécsett több éve jól múködik az integrált palliatív betegellátó rendszer, és a palliatív szakemberek rendszeresen részt vesznek az onkológiai megbeszéléseken, viziteken, sőt a pécsi Onkoterápiás Intézetben palliatív szakrendelés helyben is elérhető a betegek számára [6]. Ez a struktúra pedig alapjául szolgált annak, hogy rendszeresek voltak konzultációk a két szakma között, már az elmúlt években is számtalan előrehaladott daganatos beteg további ellátását beszéltük meg közösen. Összességében ez az elhivatottság, a szakmai háttér és az együtt gondolkodás vezetett a Pécsi Tudományegyetem Klinikai Központjában ahhoz a lépéshez, hogy 2019 tavaszán megalapítsuk, elindítsuk az ún. palliatív onkoteam (POT)megbeszéléseket, strukturális keretet adva az addigi szakmai együttmúködésnek. A cél az előrehaladott és/ vagy tünetes onkológiai betegek időben történő és megfelelő palliatív ellátásba kerülése, illetve a további onkoterápiás lehetőségek megítélése és a felesleges kivizsgálások, illetve kezelések elkerülése volt. Az első hónapok észrevételei alapján eme - hazai szinten mindenképpen, de nemzetközi viszonylatban is sok szempontból úttörőnek számító - orvosi, pszichológusi és szakdolgozói grémium munkájáról, tapasztalatairól szeretnénk beszámolni.

\section{Módszer és eredmények}

2019 késő tavaszától kezdve a POT-megbeszéléseket általában kéthetente tartottuk meg, a helyszín a Pécsi Tudományegyetem Klinikai Központjának Onkoterápiás Intézete, illetve az intézet konzultációs helyisége volt. A team állandó tagjai palliatív szakemberek, palliatív-hospice és onkológiai szakápolók, pszichológus, illetve klinikai onkológus, belgyógyász, aneszteziológus, pszichiáter szakorvosok voltak, de időszakosan nőgyógyász, gégész, sebész kollégák is csatlakoztak a szakmai fórumhoz. Egyegy megbeszélésen 6-10 beteg esetét tárgyaltuk végig, és a gyarapodó tapasztalatok birtokában idővel egyre több esetet tudtunk hatékonyan átbeszélni. A referálást vagy a kezelőorvos, vagy az adott intézetbeli megbízott kolléga tette meg. Az elektronikus onkoteamkonzíliumkérés formája megegyezett a pécsi elektronikus betegregisztrációs felületen évek óta múködő onkoteamrendszer megjelenésével. Itt a diagnózis, a legfontosabb anamnesztikus adatok és az onkológiai kórtörténet mellett jelöltük a beteg általános-fizikai-mentális állapotára vonatkozó paramétereket ECOG-, WHO- és/vagy KPSskála (Karnofsky Performance Scale) szerint, továbbá a legfontosabb kísérő betegségeket, az onkológiai beteg-

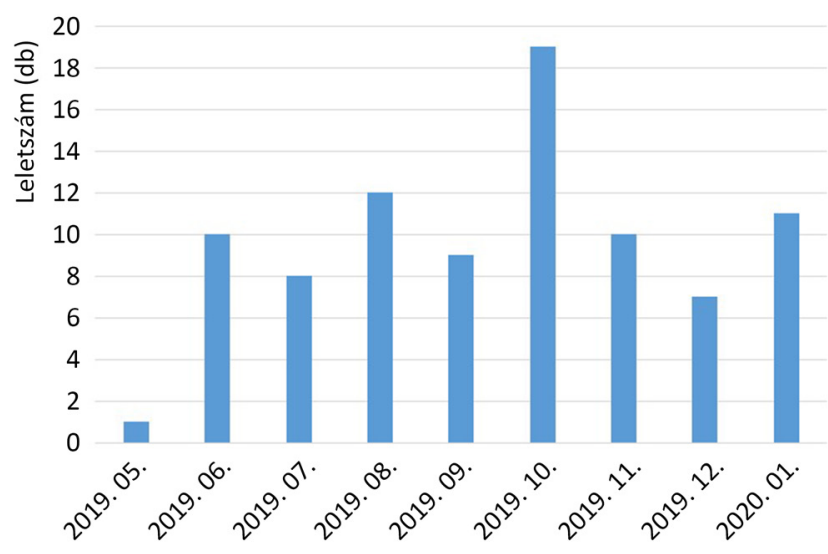

1. ábra $\quad$ A palliatív onkoteam eseti megbeszéléseinek és döntéseinek száma havi bontásban 2019 májusa és 2020 januárja között

ség szövettani típusát és stádiumát. Az esetismertetés során külön figyelemmel kísértük az addig elvégzett onkológiai kezeléseket, és azt is megbeszéltük, hogy bármilyen érdemi onkológiai terápia lehetséges-e még elvileg a továbbiakban. A további aktív onkológiai kivizsgálás és kezelés lehetôségének és klinikai hasznának megítélését követően megbeszélésre kerültek a beteg tüneti terhei, pszichés állapota, preferenciája, a családi háttér, és mindezen tényezők együttes figyelembevételével történt a legmegfelelőbb palliatív-hospice ellátás meghatározása. A megbeszélés eredményét és a team döntését mind elektronikusan, mind írott formában archiváltuk, természetesen az utóbbi papírokon szerepelt a részt vevó szakorvosok, illetve szakemberek aláírása. Az elektronikus betegrögzítő rendszerben történt archiválás pedig lehetőséget biztosított arra, hogy orvosilag indokolt esetben és az adatvédelmi szabályok megtartásával más szakorvosok, sürgősségi ellátónál dolgozó kollégák is megtekintsék a megbeszélés eredményét.

2019 májusa és 2020 januárja között 93 betegnél 97 eseti megbeszélést tartottunk (1. ábra); a beküldő a leggyakrabban az Onkoterápiás Intézet volt, 80 konzíliumkérés erről a klinikáról került feladásra, de megkeresések természetesen érkeztek más, daganatos betegeket ellátó pécsi intézményekból is. Volt olyan fiatal betegünk, akinél 3 rendkívül hosszú és minden részletre kiterjedő megbeszélést is tartottunk. Ahogy az előbbiekben említettük, valamennyi esetben meghatároztuk a beteg további palliatív ellátásának formáját (szakrendelésen való jelentkezés, otthoni szakellátás, intézeti elhelyezés) és azt, hogy adott esetben még szóba jön-e további aktív onkológiai ellátás. Ebben a döntési mechanizmusban az előzmények végigbeszélése mellett természetesen komoly szereppel bírt a betegek fizikális és mentális tartaléka, illetve általános állapota. A 2. ábra diagramján látható, hogy a konzultált betegek kb. egynegyede volt még nagyrészt önellátó állapotban $(\mathrm{ECOG} \leq 2)$, ugyanakkor a teljes ellátásra szoruló páciensek $(\mathrm{ECOG}>3)$ aránya nem haladta meg a $15 \%$-ot. 

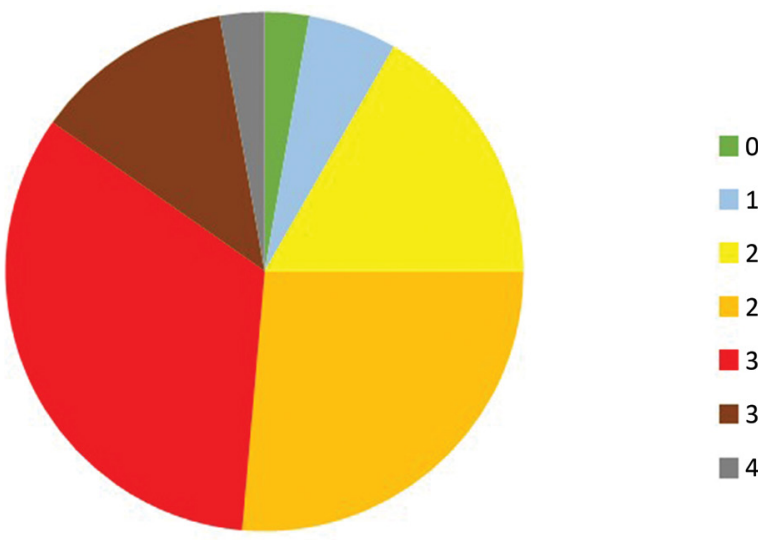

1

2

2-3

प3

3-4

4

2. ábra

\footnotetext{
A megbeszélésre beutalt betegek általános állapotának ECOG szerinti megoszlása kördiagram formában

ECOG $=$ Eastern Cooperative Oncology Group
}

A betegeknél 45 esetben javasoltunk otthoni hospiceellátást, 8 esetben hospice-osztályos elhelyezést, 4 esetben sürgős kórházi osztályos felvételt a tüneti terápia beállítására, 9 esetben palliatív szakrendelésen való megjelenést, és 27 esetben otthoni vagy kórházi palliatív konzíliumot a további ellátás formájának meghatározására. Mindezeken túlmenően több esetben megtárgyaltuk valamilyen speciális ellátási forma, alternatív táplálás, mozgásterápia, családi pszichés támogatás stb. részleteit, 4 esetben fájdalomambulanciára utaltuk a beteget invazív fájdalomcsillapítás céljából. Betegeink több mint 90\%-ánál további onkológiai kezelés nem jött szóba, 8 esetben merült fel valamilyen palliatív onkoterápiás forma (hormonterápia, fájdalomcsillapító vagy vérzéscsillapító besugárzás, palliatív kemoterápia) mérlegelése.

A megbeszélésen mindig jelen lévő palliatív-hospice szakápoló koordinátor minden esetben lejegyezte, mikor kell a beteget meglátogatni, mikor kell szakrendelési időpontot adni, illetve mikor szükséges a beteg osztályos elhelyezését elindítani. A palliatív szakellátásba vonást azonban 2 esetben sajnos megakadályozta a beteg korai, néhány napon belül bekövetkező elhalálozása. A döntésről történő tájékoztatás alapvetően három úton történt:

1) Az onkológus kezelőorvos az esetek többségében már jelezte, hogy hatékony onkológiai terápia már nem lehetséges, ső́t a további kezelés a szövődmények fokozott kockázatát vonja magával, és más utakat kell keresni.

2) A palliatív ellátás szükségességéről és formájáról a palliatív szakemberek világosították fel a beteget.

3) A fejlődés egyfajta jeleként azonban több esetben a két szakorvos (onkológus, palliatív orvos) együtt ült le a beteggel és a hozzátartozókkal, végigbeszélve a lehetőségeket és a további ellátás formáját, céljait.

Összességében az esetek kb. felében a kezelőorvos már előzetesen konzultált a palliatív team tagjaival, más esetekben a POT-megbeszélést követően kereste fel/ hívta be szakrendelésre a beteget a palliatív szakember.

A POT-megbeszélések első eredményének mindenképpen az tekinthetô, hogy a kezdeti, sokszor feszültség-

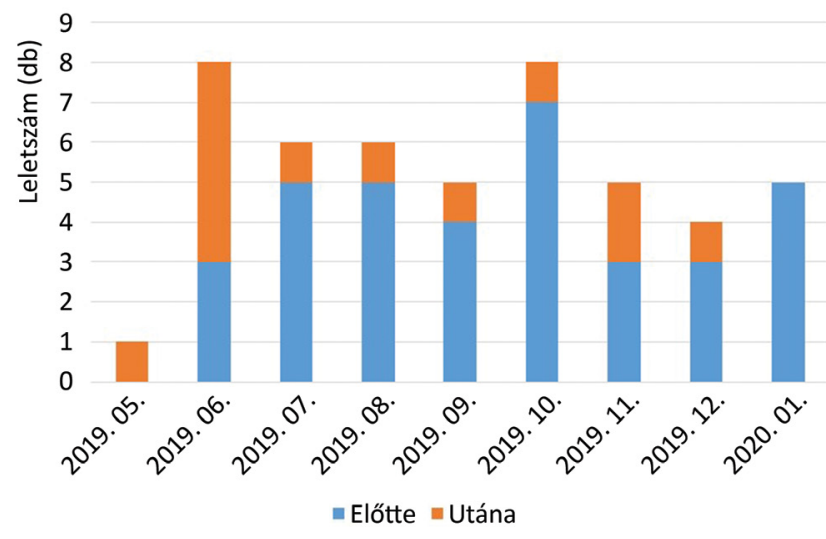

3. ábra

A palliatív onkoteam döntéseit megelőző és azt követő, sürgősségi ellátónál történt megjelenések arányának időbeli változása 2019. május és 2020. január közepe között (2020. februári felmérés)

gel jellemezhető, indulatoktól sem mentes konzultációk néhány hónap elteltével konszolidált, tanulságos és hatékony szakmai fórumokká alakultak. El kell ismerni azt is, hogy a kezdeti indulatok elsősorban az onkológiai oldalról érkeztek, hiszen sokszor igen nehéz és felelősségteljes kimondani azt, hogy további aktív onkoterápia nem jön szóba. A rendszer fejlődésének jele az is, hogy míg az első időszakban egy-egy esetmegbeszélés 15-20 percig is eltartott, addig pár alkalom után egy óra alatt akár 10 beteg esetét is meg tudtuk tárgyalni. A szubjektív fejlödés mellett azonban legalább olyan fontosak az objektív eredmények, amelyeket esetünkben a felesleges sürgősségi megjelenések számában lehet lemérni. A megbeszélésre került betegek esetében pár hónap eltelte után ebben a mutatóban egyértelmú csökkenés mutatkozott (3. ábra). Az ebbőll a szempontból vizsgált időszakot (2019. június-2020. január) két részre bontva, a POT előtti sürgősségi megjelenések száma érdemben nem változott (17 vs. 18), ugyanakkor a POT utáni sürgősségi ellátások száma gyakorlatilag megfeleződött (8 vs. 4). Ezeket az eredményeket természetesen torzíthatja a kezdeti, még nem teljesen összehangolt múködés, illetve az a tény, hogy a vizsgált időszak utolsó hónapjaiban megbeszélt betegesetek kapcsán még később is történhet sürgősségi beutalás. Mégis úgy gondoljuk, hogy ez a tendencia mindenképpen eredménynek tekinthető.

\section{Megbeszélés}

A csapatmunka, a közös döntési folyamat, az együttes jóváhagyás, illetve a különböző szakterületek, különböző szakértők közös megbeszélései mára már a mindennapok részévé váltak az onkológiai betegellátásban. Ezek a közös megbeszélések a magyar szóhasználatban az „onkoteamek”, ugyanakkor az angol nyelvü szakirodalomban inkább a "tumor board” kifejezés terjedt el [26-28]. A közös megbeszélések célja a bizonyítékokon alapuló orvosi tudásbázis és a közös bölcsesség felhasználásával a beteg állapotához mért optimális terápia 
meghatározása, hiszen számtalan tényezőtől, szövettani altípustól, stádiumtól, kísérő betegségektől stb. függően az egyes betegek számára leghatékonyabb kezelési formák, kombinációk igen jelentősen eltérhetnek. Ám eme szakmai összejövetelek megtartásának célja nem kizárólag a beteg számára legjobb, lehetőség szerint evidenciákra alapozott, „személyre szabott”, ugyanakkor jogilag is megerósített beavatkozás kiválasztása, hanem ezek a teammegbeszélések egyúttal továbbképzések és a gyógyító orvoskollégák számára egyfajta pszichoterápiás segítségnyújtó fórumok is [26]. Az első kitétel egyértelmú, hiszen egymástól is tanulunk, a második talán némi magyarázatra szorul. Az orvosi dilemmák, kétségek megbeszélése, a közös felelősség, a másoktól érkező megerősítés mind-mind segíti egyensúlyban tartani a kezelőorvos lelki világát, hiszen egy potenciálisan fatális és még a mai napig rettegett betegség esetében egyedül sokszor nehéz kimondani a végső szót vagy a minden szempontot figyelembe vevő „legjobb” döntést hozni, ugyanis a mindennapi valóságban nem mindig tudhatjuk döntésünk több hónapra, több évre előrevetített helyességét.

A kuratív, gyógyító jellegű onkológiai kezelések során a terápiás döntés maximálisan optimista, bízunk a beteg teljes gyógyulásában, ezt közvetítjük a beteg felé is, és egy esetleges öt vagy tizenöt év múlva bekövetkező kiújulás minimális valószínûsége a kezelőorvos lelkivilágát alig nyomasztja, illetve a páciensek közül is csak a fokozott betegségtudattal rendelkezőket tölti el némi megelőlegezett szorongással a visszaesés kockázata. Áttétes betegségek kezelése során az első vonalban többnyire még fennáll az optimizmus, az orvos és a beteg is várja a terápia hatását, a betegség zsugorodását, jó esetben eltünését, müthetővé válását. $S$ itt az előrevetített idő a kezelőszemélyzet szemszögéből sok-sok hónap, esetleg néhány év, ez pedig még a gyógyítás érzését kelti a kezelőorvosban. Másod- és harmadvonalban már némileg csökken a jövőbe vetett hit, de még valamennyire mind a kezelőszemélyzet, mind a beteg és a hozzátartozók várják a hatást, a csodát, de már ott lebeg mindenki lelki szeme előtt az a lehetőség, hogy terápiarezisztens betegségról van szó. Itt pedig még általában hónapokról van szó.

A sokadik vonalbeli terápiák már általában csak pár hét hatékonysággal kecsegtetnek, alig többel, mint amit a természetes betegséglezajlás jelent. Ez már nyomasztó mindenki számára, a beteg érzi, az orvos tudja, hogy nagy a baj, de az őszinte kommunikáció, a felkészítés még sokszor ilyenkor sem történik meg. A mai modern orvostudomány ismereteinek birtokában nagyon nehéz kimondani és elismerni, hogy érdemben már nem tudunk időt és életet adni, nem tudunk „gyógyítani”. Ezen a szörnyü nehéz ponton a legtöbb kezelőorvos megakad, néha indulatossá válik, időnként a beteggel együtt az alternatív medicina területeire téved, vagy ami ilyenkor talán gyakoribb, a multigénes molekuláris patológiai vizsgálatok mindent megmondó-megoldó bűvkörébe kerül. Az utóbbi gondolat, a „személyre szabott” ellátás sok betegnek is igénye, hiszen ez a betegnek azt jelenti, hogy most célzottan ôt gyógyítják, mégpedig azon hiba kiiktatásával, amely csak az ő betegségére, bajára jellemző.

Az orvosnak pedig, ha ebben a betegségszakaszban van is a kezében a közös orvosi bölcsességet kifejező onkoteamdöntés, többnyire a BSC (best supportive care) hárombetús „ítélettel” nehéz mit kezdenie, biztos iránymutatást ez nem ad. Ilyenkor közöljük, hogy a továbbiakban nem tudunk segíteni, vagy jobb esetben felvesszük a kapcsolatot valamely palliatív szakemberrel, de akkor is sokszor az a rossz érzés marad a kezelőorvosban, hogy a rábízott feladattal nem tudott megbirkózni. Ez a fajta dilemma, insufficientiaérzés rendkívüli terheket ró az onkológusra, és többnyire ilyenkor már nincs lehetőség ismételt és ismételt iránymutató onkoteammegbeszélésekre sem. Ráadásul a kelet-európai medicinára még mindig inkább jellemző a (sokszor bizalmat és hitelességet biztosító) közvetlen és szoros orvos-beteg kapcsolat, egyfajta egymásrautaltság, így sok onkológus nem is veszi jó szemmel, ha valaki átveszi a szerepét, és az ő betegével kezd foglalkozni. Ilyenkor az onkológus kezelőorvos próbálja a beteg palliatív ellátását, fájdalomcsillapítását, roborálását megfelelő mederben tartani, és legfeljebb hospice-osztályos felvétel esetén mond le a rábízott feladatról. A másik véglet a „cinikus” hozzáállás: a BSC itt azt jelenti, hogy nekem már nem kell foglalkoznom a beteggel, a páciens, ha problémája van, forduljon a háziorvosához vagy a sürgősségi ellátóhoz.

Ebben az embert (orvost és beteget) próbáló helyzetben a betegek egy része elkerül palliatív szakemberhez, ahol a megfelelő egyéni kezelési tervet a beteg tünetei, preferenciái szerint állítják össze, és reális ellátási célok kerülnek meghatározásra. Másik részüket az előbb említetteknek megfelelően a lelkiismeretes kezelőorvos próbálja még támogatni, istápolni, de ennek a támogatásnak a hatékonysága fokozatosan csökken, és nagyon sok beteg utolsó időszakbeli sorsa megoldatlan marad. Ez a légüres térbe kerülés pedig rengeteg csalódottság és indulat forrása lehet. Persze minden betegnek az emberhez méltó sorsát és megfelelő, tünetorientált kezelését nem is lehet megoldani, de törekedni kell arra, hogy a betegek többsége az állapotához igazodó palliatív ellátási formában tudjon részesülni.

A gyakorló onkológusok számára a palliatív kifejezés egy kicsit mást is jelent. Palliatív onkológiai kezelésről akkor beszélünk, ha valamilyen terápia elsődleges célja nem a beteg teljes gyógyulásának elérése és nem is feltétlenül a túlélési idő növelése, hanem a kezelés fő irányultsága a tünetek enyhítése és a gyors állapotromlás megelőzése. Ezen terápiás attitûd pedig legalább kétszáz évre, még a manapság használatos onkoterápiás módszerek megjelenése előtti időszakra vezethető vissza [29]. Tehát a gyógyító attitűd mellett a „csak” segítő hozzáállás is ott lakozik minden onkológus lelkében, de azt a fajta segítést teljességre törekvő tüneti ellátással már nem mindig tudjuk kiegészíteni, és sokszor a tünetek, fájdal- 
mak azonnali csillapítása helyett inkább várakozunk az onkoterápia szimptómás hatására. Ugyanakkor a legújabb irányelvek már ebben az időszakban a palliatív ellátás megkezdését, a korai palliatív gondozásba vételt javasolják [1-6, 18-25]. Saját felmérésünkben a konzultáció idején a betegek kb. egynegyede volt még jónak mondható, munkaképes és/vagy önellátó állapotban.

Ilyenkor nehéz dönteni, meddig terjed az onkológus orvosi hatásköre, mikor teszek jobbat a beteggel, ha még gyógyulási hitet tartok benne, vagy ha időben próbálom felkészíteni a várható rövid prognózisra, és egyúttal igyekszem a beteg életminőségét javítani. Kérdés az is, hogy mikor javasolható egyfajta kettős gondozás, miután a nemzetközi gyakorlatban sok helyen a palliatív szakember és az onkológus kezelőorvos közösen követi a beteget $[23,24,30]$, avagy meddig szükséges fenntartani, megadni az egyszemélyes orvos-beteg kötődés lehetőségét, szokását. A mi gyakorlatunkban a kettős gondozás is többször előfordul, amit a betegek, családok pozitívumként fogadnak, hiszen nagyobb egyéni figyelem fordul feléjük, és komplexebb ellátásban részesülnek.

A különböző betegutak, kommunikációs és konzultációs formák, amíg a beteg eljut a palliatív ellátókhoz, igen sokrétüek kórházak, régiók, országok és szokások szerint [18, 19, 23-25, 31-34]. Egyébiránt a szakirodalom különböző attitüdöket és modelleket ismer a palliatív ellátásba lépés kérdéskörével kapcsolatban, léteznek betegség-, illetve betegcentrikus, továbbá probléma- és tünetorientált megközelítések, és a kezelésátadást illetően lehet teljes váltásról, illetve egyfajta folyamatról beszélni $[30,35]$. Persze az optimális cél az integrált onkológiai-palliatív rendszerek kialakítása [1-4, 30, 35].

A mindennapokban azonban kérdés, hogy mikor és milyen formában kell a palliatív szakember segítségét kérni, és azt is szükséges végiggondolni, hogy miképpen tudjuk kihasználni a rendelkezésre álló egészségügyi kapacitásokat, valamint azt is tudni kell, hogy kötelességünk fölöslegesen nem terhelni az egészségügy korlátozott anyagi forrásait. Embert próbáló kérdések, és ezért látszik célszerünek itt is a csapatmunkát és a közös döntési felelősséget bevonni az optimális betegellátás érdekében. Elvileg a multidiszciplináris onkoteammegbeszéléseken javasolt a palliatív szakember részvétele, de ez általánosságban nehezen kivitelezhető $[1,30,36]$, hiszen a legalább tízféle sokszakmás fórumokon (és mellette esetleg az onkológiai osztályos referálókon) való többórás ottlét szinte képtelenség, azt is figyelembe véve, hogy az esetek döntő részében valamilyen speciális onkoterápiás beavatkozás lehetőségeinek elbírálásáról esik szó. Ez pedig a szúkös palliatív szakember-ellátottság mellett nem nagyon férhet bele a mindennapi rutinba.

Persze ismertek a nemzetközi vagy akár a hazai gyakorlatban különböző palliatív eseti teammegbeszélések, különböző multidiszciplináris fórumok, amelyeken a palliatív ellátásba vont betegek kezelési tervét beszélik meg; és számtalan javaslatot is találhatunk az optimális teammúködés megszervezésére, de tudni kell, hogy eze- ken a fórumokon nem rutinrésztvevők a klinikai onkológusok vagy a sugaras szakemberek $[32,36]$. Itt kell azonban megemlíteni, hogy Barth és mtsai éppen 2020 márciusában ismertették egy franciaországi onkológiai központ teammúködését, ahol az onkológusok és a palliatív szakorvosok közösen egyeztetik az előrehaladott daganatos betegek további ellátását [25]. A pécsi kezdeményezés újdonsága hasonlóképpen éppen az, hogy a gyakorló onkológusok és a palliatív medicina szakemberei együtt beszélik meg a dilemmákat, így biztosítva a beteg számára az optimális és reális ellátást. A csapatmunkára épülő átadás-átvétel pedig csökkenti az onkológusra nehezedő terheket, a palliatív szakember elérhető célokat tud megfogalmazni a beteg számára, miközben az ellátórendszer egészének hitelessége minden szinten fenn tud maradni.

\section{Következtetés}

Mindezen tényezők miatt látszott célszerünek egy külön fórum megszervezése az előrehaladott, többnyire tünetes, komplex ellátási igényű daganatos betegek palliatív ellátásának megbeszélésére és megszervezésére. Ez a fórum megalapozhatja a rendelkezésre álló egészségügyi erőforrások racionális felhasználását és a beteg számára is igen megterhelő életvégi kivizsgálások és onkológiai kezelések arányának jelentős csökkentését. A Pécsi Tudományegyetem Klinikai Központjában megszervezett POT-megbeszélések ezeket a nagyon fontos célokat szolgálják. Tapasztalataink szerint ezek a közös konzultációk valóban orvosszakmai megalapozottságú, operatív, tanulságos, ugyanakkor emberközeli konzultációs fórummá válhatnak, ahol a beteg állapotának és valós szükségleteinek megfelelő kezelési terv kerül meghatározásra a multidiszciplináris team által. Persze célunk az együttmúködés továbbfejlesztése, de a világszerte növekedő számú daganatos megbetegedések és az egészségügyi rendszerek sokszor szúkös erőforrásai miatt javasoljuk ezen betegellátási és klinikai minőségbiztosítási megbeszélések megszervezését más egészségügyi intézményekben is, nem feledve azt az alaptételt, miszerint bizonyos helyzetekben a gyógyító onkológiai attitüd fokozatosan segítő orvosi hozzáállássá kell, hogy alakuljon.

Anyagi támogatás: A szerzők nem részesültek a közlemény megírásával kapcsolatos anyagi támogatásban.

Egyéb támogatás: A szerzők közül többen (M. L., S. H., Cs. Á.) résztvevői az EFOP-1.8.0-VEKOP-17 (Egészségügyi ellátórendszer szakmai módszertani fejlesztése; "Jógyakorlat”) és a GINOP-2.2.1-15-2017-00067 (Hálózatos analitikai és adathasznositási lehetôségek az egészségügyben”) országos pályázatoknak. Ezen projektek a közlemény megírását közvetlen módon nem támogatták, de oktatási anyagok elkészítése, konzultációk kapcsán sokban segítették a közlemény tartalmi összeállítását. 
Szerzôi munkamegosztás: M. L.: Az alapteória megalkotása és a közlemény megírása. L. M.: Adatgyújtés, betegkövetés. H. A.: A közlemény véleményezése. S. H.: Irodalomkutatás, az ábrák elkészítése. K. P., S. A.: Az alapteória megalkotása. Cs. Á.: Az alapteória megalkotása és a közlemény véleményezése. Az onkoteam állandó tagjai: F.-M. M., V. Zs., H. E., P. E., J. I. Zs., Sz. N., A. R., F. S., M. L., L. M., H. A., Cs. Á. A cikk végleges változatát valamennyi szerző elolvasta és jóváhagyta.

Érdekeltségek: A szerzőknek nincsenek a közlemény tartalmával kapcsolatos érdekeltségeik.

\section{Köszönetnyilvánítás}

Ezúton köszönjük a Pécsi Tudományegyetem Klinikai Központjának a palliatív onkoteam múködésének kezdetétől való támogatását. Szintén köszönjük a palliatív betegellátás valamennyi szegmensében közremúködő orvos és ápoló odaadó munkáját. Végezetül külön személyes köszönetünket fejezzük ki Udvardy György volt pécsi római katolikus megyéspüspök úrnak, aki a kezdeti döntéshozatal lelki dilemmáit meghallgatta, és a további munkánkat sokat jelentő szavakkal támogatta.

\section{Irodalom}

[1] Ferrell BR, Temel JS, Temin S. et al. Integration of palliative care into standard oncology care: American Society of Clinical Oncology clinical practice guideline update. J Clin Oncol. 2017; 35: 96-112.

[2] Kaasa S, Loge JH, Aapro M, et al. Integration of oncology and palliative care: a Lancet Oncology Commission. Lancet Oncol. 2018; 19: e588-e653.

[3] Schuler US. Early integration of palliative and oncological care: con. Oncol Res Treat. 2019; 42: 19-24.

[4] Kamal AH, Bausewein C, Casarett DJ, et al. Standards, guidelines, and quality measures for successful specialty palliative care integration into oncology: current approaches and future directions. J Clin Oncol. 2020; 38: 987-994.

[5] Ferrell BR, Chung V, Koczywas M, et al. Dissemination and implementation of palliative care in oncology. J Clin Oncol. 2020; 38: 995-1001.

[6] Benyó G, Lukács M, Busa C et. al. Current situation of palliative care in Hungary. Integrated palliative care model as a breakout possibility. [A magyarországi palliatív-hospice ellátás helyzete, kihívásai, kitörési pontjai.] Magy Onkol. 2017; 61: 292-299. [Hungarian]

[7] Csikós Á. (ed.) Palliative care. [Palliatív ellátás.] Egyetemi jegyzet, Pécsi Tudományegyetem, Pécs, 2015. [Hungarian]

[8] Muszbek K, Ruzsa A. Supportive palliative treatment, psychological care and the hospice movement in Hungary. Support Care Cancer 1996; 4: 7-9.

[9] Hegedús K, Lukács M, Schaffer J, et al. The current state, the possibilities and difficulties of palliative and hospice care in Hungary. [A hazai hospice- és palliatív ellátás helyzete, lehetőségei, nehézségei.] Orv Hetil. 2014; 155: 1504-1509. [Hungarian]

[10] Csikós A, Busa C, Muszbek K. Hospice palliative care development in Hungary. J Pain Symptom Manage. 2018; 55(2S): S30 S35.

[11] Hegedús K. (ed.) From spirit to spirit. Psychological care of patients with advanced and terminal illness. [Lélektôl lélekig. Súlyos betegek és haldoklók pszichés gondozása.] SOTE Magatartástudományi Intézet - MAPET - Végeken Alapítvány, Budapest, 1995. [Hungarian]

[12] Bognár T, Kolosai N, Hegedús K, et al. "There should be someone to hold the hand of the dying." The analysis of deep inter- views with physicians about the difficulties of the care of the dying. [„Kellene, aki megfogná a haldokló kezét!” Orvosokkal készült mélyinterjúk elemzése a haldoklógondozás nehézségeiről.] LAM 2001; 11: 154-162. [Hungarian]

[13] Muszbek K, Gaal I. Pitfalls within the cancer-related doctor-patient communication. [Az orvos-beteg kommunikáció csapdái daganatos betegség esetén.] Orv Hetil. 2016; 157: 649-653. [Hungarian]

[14] Földesi E, Hauser P, Hegedűs K. Special aspects of medical communication in the field of pediatric oncology focusing on palliative care. $[\mathrm{Az}$ orvosi kommunikáció sajátosságai a gyermekonkológia területén, különös tekintettel a palliatív ellátásra.] Orv Hetil. 2020; 161: 323-329. [Hungarian]

[15] Basch E, Deal AM, Kris MG, et al. Symptom monitoring with patient-reported outcomes during routine cancer treatment: a randomized controlled trial. J Clin Oncol. 2016; 34: 557-565. [Corrections: J Clin Oncol. 2016; 34: 2198; J Clin Oncol. 2019; 37: 528.]

[16] Basch E, Deal AM, Dueck AC, et al. Overall survival results of a trial assessing patient-reported outcomes for symptom monitoring during routine cancer treatment. JAMA 2017; 318: 197198.

[17] Vanbutsele G, Pardon K, Van Belle S, et al. Effect of early and systematic integration of palliative care in patients with advanced cancer: a randomised controlled trial. Lancet Oncol. 2018; 19 : 394-404.

[18] Pochop L, Alexandrová R, Sláma O, et al. Oncology case report - when is the appropriate time to integrate palliative care? Klin Onkol. 2019; 32: 303-305.

[19] Grosek S, Orazem M, Groselj U. Notes on the development of the Slovenian ethical recommendations for decision-making on treatment and palliative care of patients at the end of life in intensive care medicine. Pediatr Crit Care Med. 2018; 19(8S Suppl 2): $S 48-S 52$.

[20] Preisler M, Heuse S, Riemer M, et al. Early integration of palliative cancer care: patients' and caregivers' challenges, treatment preferences, and knowledge of illness and treatment throughout the cancer trajectory. Support Care Cancer 2018; 26: 921-931.

[21] Gärtner J, Daun M, Wolf J, et al. Early palliative care: pro, but please be precise! Oncol Res Treat. 2019; 42: 11-18.

[22] Kayastha N, LeBlanc TW. When to integrate palliative care in the trajectory of cancer care. Curr Treat Options Oncol. 2020; 21 : 41.

[23] Brenne AT, Knudsen AK, Raj SX, et al. Fully integrated oncology and palliative care services at a local hospital in Mid-Norway: development and operation of an innovative care delivery model. Pain Ther. 2020; 9: 297-318.

[24] Hjermstad MJ, Aass N, Andersen S, et al. PALLiON - PALLiative care Integrated in ONcology: study protocol for a Norwegian national cluster-randomized control trial with a complex intervention of early integration of palliative care. Trials 2020; 21: 303.

[25] Barth C, Colombet I, Montheil V, et al. First referral to an integrated onco-palliative care program: a retrospective analysis of its timing. BMC Palliat Care 2020; 19: 31.

[26] Mangel L, Kövér E, Szilágyi I, et al. Novel quality assurance method in oncology: the two-level, multi-disciplinary and oncotherapy oncology team system. [Új típusú minőségbiztosítás az onkológiában: a kétlépcsős (multidiszciplináris és onkoterápiás) onkoteamrendszer.] Orv Hetil. 2012; 153: 1984-1991. [Hungarian]

[27] Pillay B, Wootten AC, Crowe H, et al. The impact of multidisciplinary team meetings on patient assessment, management and outcomes in oncology settings: a systemic review of the literature. Cancer Treat Rev. 2016; 42: 56-72.

[28] Specchia ML, Frisicale EM, Carini E, et al. The impact of tumor board on cancer care: evidence from an umbrella review. BMC Health Serv Res. 2020; 20: 73. 
[29] Androutsos G, Koutsilieris M, Protogerou A, et al. Popular palliative cancer treatments in 18th-mid 19th century. J BUON 2016; 21: 523-527.

[30] Hui D, Bruera E. Models of integration of oncology and palliative care. Ann Palliat Med. 2015; 4: 89-98.

[31] den Herder-van der Eerden M, van Wijngaarden J, Payne S, et al. Integrated palliative care is about professional networking rather than standardisation of care: a qualitative study with healthcare professionals in 19 integrated palliative care initiatives in five European countries. Palliat Med. 2018; 32: 1091-1102.

[32] Siouta N, Van Beek K, van der Eerden ME, et al. Integrated palliative care in Europe: a qualitative systematic literature review of empirically-tested models in cancer and chronic disease. BMC Palliat Care 2016; 15: 56

[33] Paiva CE, de Freitas Seriaco FL, de Angelis Nascimento MS, et al. Missed opportunities of integration of palliative care: frequency, causes, and profile of missed visits in an oncologic palliative care outpatient unit. J Pain Symptom Manage. 2020; 59: 10671073.el.

[34] Vanbutsele G, Van Belle S, Surmont V, et al. The effect of early and systematic integration of palliative care in oncology on quality of life and health care use near the end of life: a randomised controlled trial. Eur J Cancer 2020; 124: 186-193.

[35] Burt M, Kamal AH. Practical strategies for optimizing and integrating palliative care in cancer. Curr Oncol Rep. 2018; 20: 97.

[36] Furman M, Harild L, Anderson M, et al. The development of practice guidelines for a palliative care multidisciplinary case conference. J Pain Symptom Manage. 2018; 55: 395-401.

(Mangel László dr., Pécs, Édesanyák útja 17., 7624 e-mail: mangel.laszlo@pte.hu)

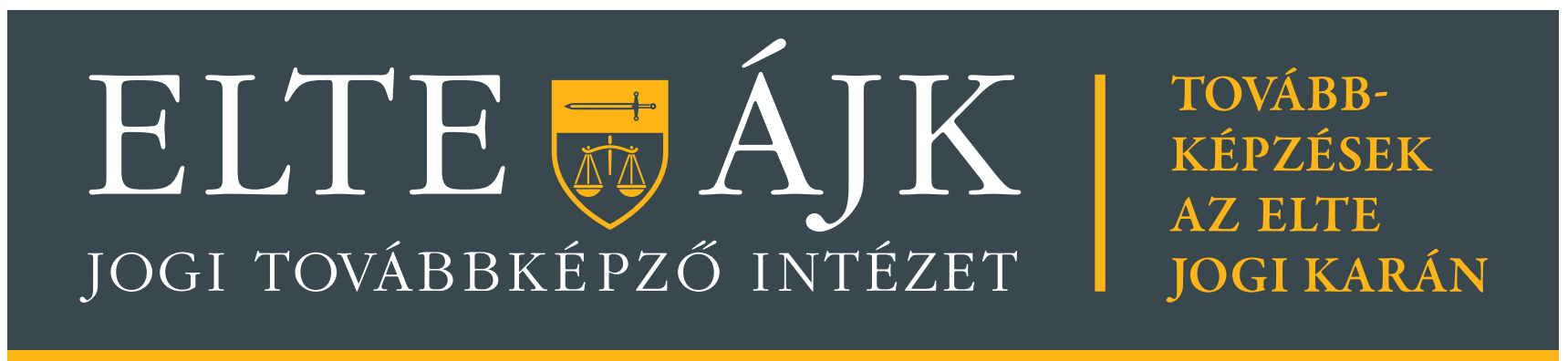

\section{Helyszín:}

ELTE Főépület,

1053 Budapest,

Egyetem tér 1-3.

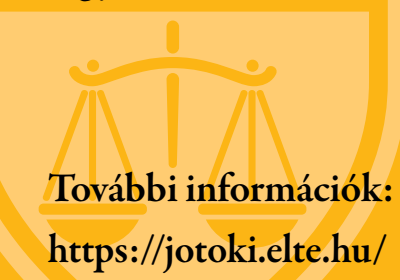

A cikk a Creative Commons Attribution 4.0 International License (https://creativecommons.org/licenses/by/4.0/) feltételei szerint publikált Open Access közlemény melynek szellemében a cikk bármilyen médiumban szabadon felhasználható, megosztható és újraközölhető, feltéve, hogy az eredeti szerző és a közlés helye, illetve a CC License linkje és az esetlegesen végrehajtott módosítások feltüntetésre kerülnek. (SID_1) 